\title{
Communication Behavior in Political Life Ethnic Java at Medan
}

\author{
Katimin $^{1}$, Syukur Kholil ${ }^{2}$, Junaidi ${ }^{3}$ \\ ${ }^{1,3}$ Faculty of Ushuluddin and Islamic Studies, Universitas Islam Negeri Sumatera Utara, Indonesia \\ ${ }^{2}$ Faculty of Dakwah and Communication, Universitas Islam Negeri Sumatera Utara, Indonesia \\ junaidi@uinsu.ac.id
}

\begin{abstract}
Javanese ethnicity is the most ethnic group in Medan City, so politically the opportunity to occupy political positions such as the Regional Head is very large, but until the 2019 elections the Mayor of Medan was never held by the Javanese ethnic group. This study aims to determine and analyze the motives underlying Communication Behavior in Political Life / Political Choice of ethnic Javanese Muslims in Medan. This research uses descriptive qualitative research with a phenomenological approach. Data obtained through interviews and direct observation. The results of the study mentioned that there are 4 motives underlying the behavior of communication in the political life of ethnic Javanese Muslims in Medan, specifically related to political choices, namely religious, economic, competence, and commitment to commitment.
\end{abstract}

Keywords

Behavior, Javanese ethnicity, political life

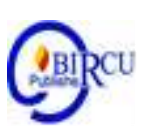

\section{Introduction}

Based on 2010 Central Statistics Agency census data, Javanese are the first ethnic group in the city of Medan as many as 33.03\%. 2,229,408 inhabitants in the city of Medan were Javanese (BPS North Sumatra Provision, 2019). Politically, if this large number is managed as well as possible, the opportunity of Javanese to sit as regional head/mayor in Medan is very large, especially since the regional head election system in this country is carried out directly. But in reality until now the Mayor of Medan has never been held by the Javanese, whereas when the Democratic Party took place, the Javanese became one of the ethnic groups that counted especially in Medan City even though if at the map of National politics, National leadership in Indonesia (President) has always been held by Javanese. Based on the facts above, it is necessary to conduct a study of communication behavior in Javanese ethnic political life in the city of Medan, by asking the question "What are the motives that underlie the communication behavior in the political life (political choice) of ethnic Javanese in Medan?" This study was conducted with the aim of analyzing the motives underlying the communication behavior in political life, especially the political choices of ethnic Javanese in the city of Medan.

\section{Review of Literatures}

\subsection{The Basic Concepts of Behavior}

Human behavior is called behavior. Biologically, behavior is defined as "the activity of organisms that have a wide range". According to Soekidjo, behavior is "all human activities that can be either directly observed or cannot be directly observed". (Soekidjo Notoatmodjo, 2007). Meanwhile, Solita Sarwono has a definition that "human behavior is the result of all kinds of human experiences and interactions with the 
environment that are manifested in form of knowledge, attitudes and actions". (Sarwono, 2013).

According to Notoatmojo, human behavior appear in order to respond or as a reaction to stimulus (Soekidjo Notoatmodjo, 2007). Stimulus can come from itself or from outside (the environment). Meanwhile, according to the Ministry of National Education, behavior is "the response or reaction of individuals to stimuli or the environment" (Department of National Education, 2005).

The relationship between stimulus and action is a causal relationship. The power that influences human behavior, not only the power which comes from the current environment, but also past experience and also the influence of the future in order to guarantee human existence (Ibrahim, 2001).

In general, human behavior has a goal orientation, it means that human behavior is based on or motivated by a desire to obtain certain goals, this is what is called a stimulus that comes from outside or external factors. As explained by Ichsan that behavior is "an activity carried out by an individual due to external stimulus." (Ichsan, 2010).

In addition to external factors, human behavior is also influenced by the strength itself. Individuals have interests, insights, emotions, thoughts and motives that coloring their actions. All of these will drive human activities, including communication activities and other activities. The emergence of a certain behavior, is not solely stimulated by external stimuli or external situations, but also determined by cognitive selection. (Bimo Walgito, 2003).

According to Moefad, the behavior occurs because of strong impulses from oneself within a person, who is thought, believed and what he feels, those impulses are called motivation (Moefad, 2007).

Motivation is a factor that causes a certain activity to be dominant when compared to other activities, which causes the individual to act or act. (Uno, 2011) On the other hand, Sondang states that the motation comes from the word motive. According to him, the motive is a state of obligation to encourage activating or moving and that motive is directing and channeling the behavior, attitudes and actions of a person related to achieving goals both the goals of one's organization and the personal goals of each member of the organization concerned. "(Siagian, 2004)

According to Nana Syaodih, motivation is "a force that drives individual activities." (Syaodih S, 2007) While Mc Donald, as quoted by Sardiman AM defines motivation is a change in energy in a person characterized by the emergence of feelings and preceded by responses to the existence of goals (Sardiman, 2012)

If we pay attention to human behavior in personal life and interpersonal life, then the question will arise about two things namely why someone chooses an action and rejects another action. Then the second why would want to maintain his actions in a long time despite many obstacles.

A person's behavior is influenced by two motivations, namely positive motivation and negative motivation, this motivation encourages humans to move toward the desired object or condition or desires and needs.

According to Soekidjo, behavior is divided into two types, namely passive behavior and active behavior. Passive behavior is an internal response, which is what happens within humans and cannot be directly seen by others, for example thinking, responses or attitudes and knowledge. Active behavior that is if the behavior is clearly observable directly. For example actions and actions that appear. (Soekidjo Notoatmodjo, 2007)

According to Benjamin Bloom, there are three basic aspects that affect behavior, namely aspects of knowledge (cognitive domain), aspects of attitude (affective domain) and 
aspects of behavior (psychomotor domain). The knowledge aspect is a basic aspect in changing one's behavior. This aspect develops gradually understanding, which then continues to the stages of knowing, analyzing, synthesizing and assessing. This aspect is the background of the basic aspect of attitude (Ichsan, 2010)

The attitude aspect is a process of mental development in determining the choice to accept or reject a stimulus from outside oneself after he experiences the process of developing mental aspects of knowledge. Like the knowledge aspect, the attitude aspect also develops through several stages of accepting, and rejecting. These two stages are contrasting as the two decisive choices. In the process of development, the two contrasting stages occur the development of receiving, feeling, answering, then determining the attitude of rejecting and accepting. After this aspect of attitude develops, then the next aspect that is born aspects of action. While the aspect of the action is the next stage of the aspect of knowledge and attitude aspects. the process of development in the aspect of deeds will reach the stage of doing something.

So, the change in behavior from the onset of the development of knowledge (cognitive) which is then followed by the development of attitude (affective) and to the action or behavior (psychomotor), so that the desired healthy living behavior will be achieved if based on: (1) knowledge, (2 ) attitude, as an embodiment of mental attitude and reflection of the insights that are owned are also basic in making decisions, and (3) actions in carrying out daily activities should always be guided by rules that are in line with the norms of daily life.

\subsection{Communication Behavior}

Communication behavior according to communication science which is the act or activity of a person or audience when involved in the communication process. (Kuswarno, 2008) Whereas according to Siti Chatijah, communication behavior is the way an individual is in his communication activities which includes verbal communication and nonverbal communication. The way to communicate here can be in the form of speech, language selection, use of gestures, gestures, facials, and postural when a person engages in communication activities. (Chatijah, 2011) According to Devito, language as a social institution is designed, modified and developed to meet cultural needs or subcultures that continue to experience changes so that one culture or subculture has a language that is different from other cultures and subcultures. (Devito, 1986)

An example is Javanese ethnic culture which has language as a cultural identity. Javanese language has various levels, each of which has an affiliation of meaning with cultural values in Javanese ethnicity. In terms of level, there are three kinds of Javanese, namely Javanese Ngoko, Javanese Madyo and Javanese Kromo Inggil. The use of this language looks at the context of space and time and with whom the individual communicates and at the same time describes the social level of the individual who is communicating. (Chatijah, 2011)

Saundra explained that communication behavior is any activity that aims to find and obtain information from various sources and to disseminate information to any party that needs it. (Saundra Hybles and Richard R, 2007) Communication behavior is basically goaloriented in the sense of one's behavior in general motivated by the desire to obtain certain goals.

In communicating, everyone has their own characteristics which become their way of responding to problems or expressing opinions. Among them is assertive, proactive and reactive communication from an information professional point of view. 


\subsection{Javanese Political Political Communication}

Political communication is a communication activity in which there is a transmission of politically relevant information from one part of the political system, which is a dynamic element of the political system and the process of socialization, political participation, and recruitment that depends on communication. (Katimin, 2018)

Culture Political communication in this country is much colored by the culture of ethnic Javanese political communication. When communicating in daily life the Javanese are generally not vulgar and do not directly say their wishes. This practice is also practiced in political activities and ultimately becomes a distinct style in Javanese political communication. Likewise, the model of political communication that occurs in this country, is not transparent, seems embarrassed in expressing desires, and is not forthcoming (although many politicians say it is part of political tactics).

For ethnic Javanese, power is a mandate that comes from Almighty God, therefore it should not be forced and fraudulent in getting it. Because power is mandate, then running the wheel of power must be in accordance with the principle of the mandate in order to bring success as practiced by the Prophet Muhammad when leading the country. (Katimin, 2019)

\subsection{Symbolic Interaction Theory}

This theory was developed by Herbert Mead. Mead revealed that human membership in social groups will result in shared behavior which is then known as culture. At the same time, Mead also acknowledged that individuals who hold different positions in a group have different roles, thus giving rise to different behaviors.

Symbolic interaction provides an interpretation of the meaning of verbal and nonverbal messages as an objective and symbolic reality in communication. Through this theory, it can be described how the communication between ethnic Javanese and other ethnic groups in the city of Medan. In providing this interpretation, the self (self) always takes into account the meaningful interpretation of others (other) in a process of interaction with each other, and vice versa.

Interactions that occur between humans will run well and do not experience obstacles, if the symbol issued by each party conducting communication agreed upon its meaning so that all parties are able to interpret it properly. This situation can occur because the individuals involved in the interaction come from the same culture, or have previously succeeded in solving differences in meaning between them. But keep in mind that interaction with humans does not always run smoothly.

There are certain parties who might use insignificant symbols that are not meaningful to others. As a result the person must continually match their meanings and plan their actions. The quality of human behavior that is uncertain and is constantly developing such as making maps, testing, planning, delaying and improving their actions in order to respond to the actions of others. In accordance with this view, individuals negotiate their actions or behavior with the behavior or actions of others.

Blumer mentions that:

"Symbolic interaction refers to special characters that take place between people. The actor does not merely react to the actions of others but he interprets and defines the actions of others. Actors' responses, both direct and indirect, are always based on evaluating the meaning. Therefore, human interaction is bridged by the use of interpretive symbols or by discovering the actions of others. "(Zeitlin, 1995).

Blumer's opinion above is in accordance with the above Researcher's exposure. Then Blumer put forward three assumptions that underlie the symbolic interaction model. 
"First, humans act on the meaning given by the individual to their social environment. Second, meaning is directly related to social interactions carried out by individuals with their social environment. Third, meaning is created, maintained and changed through the process of interpretation carried out by individuals in dealing with their social environment."(Mulyana, 2012).

In Mead's thought which is in line with the phenomenological of Alfred Schutz it is stated:

"In face-to-face interaction the meaning of stimulation sought and interpreted by the actor typically refers to the motives of other actors. Schutz classifies these motifs as "motives for" (in order to motives) and "motives because" (because motives). The first type of motive is a goal that is described as the intentions, plans, hopes, interests, etc., desired by the actor and therefore future-oriented. The second type of motive refers to the past experience of the actor and is embedded in his knowledge which is deposited and therefore oriented to the past. "(Mulyana, 2004).

\section{Research Methods}

In order to answer the above questions, a study was conducted using qualitative methods with a phenomenological and cultural communication approach. The phenomenological approach is suitable because this study seeks to directly explore the phenomena experienced by Javanese in their political life. The cultural approach is carried out considering that Javanese are one of the ethnic groups who hold their culture wherever they are.

Data collection was carried out by means of interviews in which direct observation was integrated. Interviews were conducted with selected informants with the method of determining snow ball sampling informants. Interviews with informants were carried out in person over a period of 30 days in various locations in the city of Medan. Most of the interviews were conducted at the informant's house, at the mosque, at the school and at the place of business / sale of an informant.

\section{Results and Discussion}

\subsection{Research Results}

\section{a. Research Informant}

The research informants interviewed were all Javanese. They are called Javanese because their parents (father and mother) are Javanese, although some of the informants who were born were not on the island of Java, on the condition that they had fulfilled the specified criteria, that they had been citizens of Medan for at least 10 years. The informants consisted of men and women with diverse educational and professional backgrounds and came from different organizations / associations, some from Pujakesuma, Jaka Tingkir, Putra Solo and religious organizations.

\section{b. Motives Underlying Communication Behavior in Political Life}

Motives underlying the communication behavior in political life are related to the motives that underlie the political choices of ethnic Javanese Muslims. From the interviews conducted, researchers obtained 4 motives that underlie Javanese Ethnic communication behavior in political life (political choices / electing leaders), namely religion, economics, competence and commitment to promises, with the following explanation: 


\section{Religion}

Religion is the main basis seen in choosing a candidate for Regional Head or Legislator, because with religion it is expected that someone can carry out the mandate as well as possible. Ethnicity and organization followed by prospective politicians are not primary and only as a complement.

In Javanese ethnic view, religion must be used as the main basis for choosing leaders, because leadership is synonymous with the mandate of Allah Almighty. Therefore only people who understand the religion will be able to carry out the mandate as well as possible. This is the reason that becomes the motive for communication behavior in political life for ethnic Javanese. The following are the interview excerpts:

"If I choose based on religion. Because in my opinion, in the eyes of a religious leader it is an extension of God's hand to deal with worldly problems, then only they are close to God who is able to carry out God's mandate as well as possible ".

Javanese ethnics believe that politics is a concrete way of striving to uphold the truth and achieve the victory of da'wah, so in choosing political leaders, religion is the main reason because it is unlikely that non-Muslim people will fight for Islam. This is the reason that motivated the communication behavior in the political life of Mr. Muhammad Syahri, following the interview excerpts;

"If I choose based on religion. Because in my opinion, in the eyes of a religious leader it is an extension of God's hand to deal with worldly problems, then only they are close to God who is able to carry out God's mandate as well as possible ".

Javanese ethnics believe that politics is a concrete way of striving to uphold the truth and achieve the victory of da'wah, so in choosing political leaders, religion is the main reason because it is unlikely that non-Muslim people will fight for Islam. This is the reason that motivated the communication behavior in the political life of Mr. Muhammad Syahri, following the interview excerpts;

"I will choose based on his religion. The most obvious and strenuous struggle of Muslims for religious struggle actually exists in the political world, so far we have been deceived that religion is religion and politics is politics. In fact, we see that the actual teachings of religion will not be hampered if the power of this country is held by people who care about religion, because who else will fight for the interests of this religion if they are not Muslims ".

Choosing politicians based on religion is a measure of the quality of one's faith and Islam. A Muslim who is both Muslim and his faith will automatically choose politicians who are Muslim. If in the course of the journey the people commit violations then it becomes a personal matter concerned with Allah, and we are detached from Allah's warning not to choose friends or leaders from the experience of people who are not Muslim. This is the reason why religion is the motive for communication behavior in the political life of $\mathrm{Mr}$. Muhammad Nasir S.Pd.I, following an interview excerpt;

"If I choose based on religion, i will choose my religion, namely Islam. Because there is a prohibition from God not to choose leaders from Jews / Christians. Here is actually where our submission as Muslims and tested our Islam and faith. Regardless the candidate I chose would commit fraud, it was his business with God, I was released from the prohibition of Allah ".

Giving up leadership to Muslim candidates is the right step because it is left to those who fear God. Muslims must believe that God is all-seeing and omniscient in everything that humans do. This is the reason why religion is the motive for communication behavior in $\mathrm{Mr}$. Syahyudi's political life. The following are excerpts of the interview; 
"The most basic thing I see is his religion. Just the others. Because if he is Muslim, then at least he will have faith in a God who sees and knows all human behavior. So that even if he wants to commit fraud, he still has considerations ".

In political life, religion is a great capital that cannot be abandoned by everyone involved in it, both candidates and voters, because it is religion that will remind someone of the day of retribution for all human actions in this world. This is the reason why religion is the motive for communication behavior in Ibu Nursa'adah's political life, along with the excerpt of the interview;

"Choices I see the religion of the candidate, then see others such as vision, mission, ethnicity and others. Capital is important money and ability, but religion is the biggest capital in human life, especially someone who wants to think so, because this religion will remind people of the existence of retribution for all their deeds".

Islam teaches humans to be responsible. Muslim politicians certainly have a sense of responsibility for each of their duties. This is the reason why religion became the motive for communication behavior in the political life of Mr. Muhajir in selecting the Regional Head candidate / legislative candidate, following an interview excerpt;

"Politics actually makes it difficult, because there are many responsibilities that must be shouldered, so if I choose a candidate, I will see the religion that is adopted, namely Islam. A politician who is a Muslim he has been taught to be responsible for every task given ".

Religion must become a foundation in politics, because by religioning politicians come to know how important it is to keep promises made. Religious people, someone knows that promises are debts and debts must be paid and accounted for. This is the reason why religion is the motive for communication behavior in the political life of Mr. Ramlan, MA. The following are excerpts of the interview;

"Choosing politicians must be Muslim, that's me. Politics is identical to the promise of going back and forth. If he is a Muslim he must know that the promise is debt and debt must be paid and will be collected.

Politicians must understand that the office is a mandate from Allah, so choosing politicians must be Muslim, because in Islam it is taught about how to maintain the mandate. Diverse politicians of Islam at least cognitively know and understand about the concept of how to carry out the mandate properly. This is the reason why religion is the motive for communication behavior in the political life of Mr. Muhammad Nasir, M.Pd, following an interview excerpt;

"If I was Jun, in choosing what I saw the most initially was his religion. This politician is struggling with his words, so the easiest way to trace it is from his religion. If he is Muslim, at least he knows that the position is a mandate that comes from God and must be maintained and carried out as well as possible ".

Muslim politicians deserve to be chosen because surely he will give alms when he has wealth and income, wants to go to the mosque and give alms to poor people in need. This is the reason why religion is the motive for communication behavior in the political life of $\mathrm{Mr}$. Fery Ramananda, following an interview excerpt;

"If you choose the first side, look at the religion, Islam. Although the crew could not benefit economically, so at least if he was Muslim he would issue zakat, donations and alms, wanting to help build the mosque. This is the reason why you should choose a candidate who is Muslim ". 


\section{Economy}

Besides religion, Javanese Muslim ethnic communication behavior in political life is based on economic motives. That is, there are informants who elect candidates for the Regional / Regional Head candidates oriented to the economy, both his personal economy and the economy of the community. As stated by Mr. Robie Fanreza, following the interview excerpts;

"I'm already bored with the promises and accessories of photographs and mission vision that are scattered everywhere. Display photos that are religious and as best and obedient. On the basis of all of that, then I prefer politicians who clearly can bring real economic change both for me and for many people ".

The reason he answered this was because based on the experience so far, many prospective leaders during the campaign process all showed religious persons, but after being elected as a leader, their behavior did not show religious individuals, so it was better to choose leaders based on economic interests. The following are the interview excerpts:

"I chose a better leader who clearly had an impact on the economy and could provide material clearly, that was the most concrete of the religions that might be manipulated when he campaigned."

\section{Competence}

A political competence is a capital that must be considered specifically as a reason for choosing it. In this era, if a leader does not have good competence, it will be very difficult to bring the country to a better place. This is what makes the competence of politicians as a motive for communication behavior in the political life of Mr. Ramlan, MM in choosing prospective leaders. The following are excerpts of the interview;

"Competence is very important to be a consideration for me to choose a candidate for political leaders, because a leader who does not have the competence especially in this sophisticated era will not be able to do anything, especially in bringing change for the better".

\section{Commitment to Promises}

Politicians who are committed to the promises that are spoken deserve to be chosen and fought for regardless of whatever religion they hold, because the people they hold are their promises and words. Politics is an activity that is basically a belief, and that trust will emerge if there is a black and white stamped on it which contains a statement from a politician to realize his promises when elected as Regional Head or people's representative. This is the reason that makes the commitment to the promise as a motive for communication behavior in the political life of Mr. Supardi in choosing prospective leaders. The following are excerpts of the interview;

"Politics is an activity that basically is mutual trust, so if I have to choose, the main motive I choose is who can be the most committed to their promises, and that there must be an official agreement that can be brought before the law whose contents are the readiness and willingness of the candidate to realize. promises if elected later ".

For him, the most important is the commitment of prospective leaders, religion and ethnicity is not the main criteria for him in choosing a leader, because according to him religion for most people in Indonesia is only limited to symbols written on KTP. 


\subsection{Discussion}

From the results of the above study, the motives underlying communication behavior in the political life of ethnic Javanese in Medan can be classified into 2 categories, namely "motive because" and "motive for". The following explanation:

\section{a. Motive of Because}

Motive of because it is also called because to motive, which is a motive related to something that has happened or experience that is used as an excuse to do an act, so that past events that have been experienced are not repeated in him. As for those included in the category of motives because (due to motives) namely religion, competence and commitment to promises.

In political life, religion (Islam) is the main motive for Javanese ethnic communication behavior. For Javanese ethnic religion is considered as the main capital and base that must be owned by a politician, so that when religion is owned by politicians there is no reason to be chosen even though the politician is not from ethnic Javanese.

Throughout the history of direct regional elections, the city of Medan has never been led by a mayor with a religion other than Islam even though it was not of ethnic Javanese origin. This phenomenon shows that the main motive of Javanese in choosing a leader is religion, not ethnic / ethnicity.

The competence of politicians is also a motive for Javanese ethnic communication behavior to vote in the election. For ethnic Javanese, the competence of politicians is an important consideration after religion. Politicians who are Muslim and have competencies according to their fields are believed to be able to bring the nation's progress. The competence of politicians lies in their understanding of the objectives of political activity and their understanding of political office. Politics is not only limited to the way to get and seize the seat of power, but behind the power that has been obtained it contains a responsibility to serve the community and advance the nation.

Commitment in religious language is called istiqomah. Commitment can also mean serious. In order to be committed, a politician must make politics a vocation, because if politics is not a vocation, politicians make politics only a profession. So that all activities will be logically judged based on material and profit alone. Likewise, if the politician is elected to get a position, then the position will be used as a tool to hunt down material, seek popularity and enrich themselves and their groups.

A politician who has commitment and makes politics a vocation then he will make political activities not just a profession, but will make politics a field of struggle and he will live up to his work. He will try to make his position for the maximum benefit for the common good.

\section{b. Motives for}

Motive to be called also with the term in order to motive, the motive is related to the future. As for those included in the category of motives for (in order to motives) are economics.

The economy is classified as a motive for (in order to motive) because the informants want their own economy and other communities to be better and more prosperous, basic prices can be affordable and income/income increases. In addition, there are some ethnic Javanese who choose a politician to get money from the results of his choice, because for him anyone who sits on the bench of the Parliament or Mayor is not too important for him, the important thing is able to provide economic support, open employment opportunities so that the people's economy is better, able buy basic food. 


\section{Conclusion}

Based on the results of this research it can be concluded that communication behavior in the political life of ethnic Javanese Muslims in Medan specifically related to political choice is based on 4 motives, namely religion, economy, competence, and commitment to promises. The four motifs are divided into two categories, namely motives because (because motifs) and motives for (in order to motifs).

Javanese ethnicity in Medan does not make ethnic origin as a political choice motive, so it is natural that the city of Medan has never been led by a Mayor who is of Javanese ethnicity although the majority in Medan is Javanese.

\section{References}

Angkat, M., Katimin, and Nur, A. 2019. Construction of Religious Identity in Pakpak Culture Community in Dairi District. Budapest International Research and Critics InstituteJournal (BIRCI-Journal) (2): 487-494.

Bimo Walgito. (2003). Psikologi Sosial. Andi Offset.

BPS Provisi SUMUT. (2019). Provinsi Sumatera Utara dalam Angka (CV. Rilis Grafika (ed.)

Chatijah, S. (2011). Potret Perilaku Komunikasi Perempuan Jawa Anggota Kelompok Batik Tulis Sungging Tumpuk Imogiri Bantul. Universitas Gadjah Mada.

Departemen Pendidikan Nasional. (2005). Departemen Pendidikan Nasional.

Devito, J. A. (1986). Interpersonal Communiaction Book. Harper \& Row Publisher.

Eskandari, S. 2020. Social and Religion Paralysis in James Joyce's Short Story The Sisters: A Cultural Reading. Budapest International Research and Critics Institute-Journal (BIRCI-Journal) (1): 311-320.

Haidir, Daisy, J.P., Idayani, E. 2020. Implementation of Moral Values in Scouts (Study on Madrasah Ibtidaiyah State 1 Medan). Budapest International Research and Critics Institute-Journal (BIRCI-Journal) (3): 1403-1412

Hasbullah, Hatta, M., and Arifin, Z. 2018. Communication Pattern of Wilayatul Hisbah, Lhokseumawe City in Implementing Amar Makruf Nahi Mungkar. Budapest International Research and Critics Institute-Journal (BIRCI-Journal) (1): 194-205.

Ibrahim, R. (2001). Landasan Psikologis Pendidikan Jasmani di Sekolah Dasar (DepdiknasM).

Ichsan, M. (2010). Pendidikan Kesehatan Olahraga. Depdikbud.

Katimin. (2018). Political Communication of Partai Keadilan Sejahtera (PKS) in The Empowering of the Muslim Community in North Sumatera. International Journal of Humanities and Social Science Invention (IJHSSI, 7.

Katimin. (2019). Politik Islam; Studi Tentang Asas, Pemikiran dan Praktik dalam Sejarah politik Umat Islam. Rajawali Press.

Kuswarno, E. (2008). Etnografi Komunikasi: Suatu Pengantar dan Contoh Penelitiannya. Widya Padjadjaran.

Moefad. (2007). Perilaku Individu Dalam Masyarakat Kajian Komunikasi Sosia. elDeha Press Fakutas Dakwah IKAHA.

Mulyana, D. (2004). Komunikasi Populer; Kajian Komunikasi dan Budaya Kontemporer. Remaja Rosdakarya.

Mulyana, D. (2012). Metode Penelitian Kualitatif; Paradigma Baru Ilmu Komunikasi dan Ilmu Sosial Lainnya. Remaja Rosdakarya.

Sardiman, A. (2012). Interaksi dan Motivasi Belajar Mengajar. Grafindo Persada. 
Sarwono, S. (2013). Sosiologi Kesehatan Beberapa Konsep Beserta amplikasinya. Universitas Gadjah Mada.

Saundra Hybles dan Richard R. (2007). Weaver. Communicating Effectively. McGrawhill.

Siagian, S. P. (2004). Teori Motivasi dan Aplikasinya. Rineka Cipta.

Soekidjo Notoatmodjo. (2007). Promosi Kesehatan dan Ilmu Perilaku. Rineka Cipta.

Syaodih S, N. (2007). Landasan Psikiologi Proses Pendidikan. Remaja Rosdakarya.

Uno, H. B. (2011). Teori Motivasi dan Pengukurannya. Bumi Aksara.

Zeitlin, I. M. (1995). Memahami Kembali Sosiologi; Kritik terhadap Teori Sosiologi Kontemporer. Universitas Gadjah Mada.

\section{Interview Result}

Fery Ramananda. Hasil Wawancara. Wawancara dilakukan pada hari Rabu tanggal 5 Pebruari 2020 pukul 09.30-11.00 di Jalan Monodo Tanjung Mulia Medan

Mario Kasduri. Hasil Wawaxara. Wawancara dilakukan pada hari Ahad tanggal 26 Januari 2020 pukul 14.00-15.30 di jalan Garu I Gang.Kundur Medan Amplas Medan.

Muhajir. Hasil Wawancara. Wawancara dilakukan pada hari Ahad taggal 26 Januari 2020 pukul10.00-12.00 di Jalan Kawat 5 Tanjung Mulia Medan.

Muhammad Syahri. Hasil wawancara. Wawancara dilakukan pada hari Senin tanggal 27 Januari 2020 pukul13.00-14.30 di Sekolah MTSM 15 Medan.

Muhammad Nasir, M.Pd. Hasil Wawancara. Wawancara dilakukan pada hari Selasa tanggal 11 Pebruari 2020 pukul10.00-11.30. di jalan Purwosari Gg. Sederhana Medan.

Muhammad Nasir, S.Pd.I. Hasil Wawancara. Wawancara dilakukan pada hari Rabu tanggal 12 Pebruari 2020 pukul 10.15-11.30 di jalan Halat Medan

Nursa'adah. Hasil Wawancara. Wawancara dilakukan pada hari Jumat tanggal 10 Maret 2020 pukul 09.00-10.50 di Jalan Setia Jadi Krakatau Medan.

Ramlan, MA. Hasil Wawancara. Wawancara dilakukan pada hari Sabtu tanggal 25 Januari 2020 Pukul 14.00-16.00 di Jalan Mustafa Gg.VIII Medan

Supardi. Hasil Wawancara. Wawancara dilakukan pada hari Selasa tanggal 28 januari 2020 pukul 11.00-12.00 di Jalan Pancing I Medan.

Syahyudi. Hasil Wawancara. Wawancara dilakukan pada hari Selasa tanggal 4 Pebruari tahun 2020 pukul 16.30-18.00 di Jalan Pertempuran VII Gg. Mawar Brayan Medan. 